We figure a shell from the white chalk, one valve of an oyster with another smaller one attached to the internal surface. The first oyster must have lived and died, its animal substance must have been decomposed, or have been eaten out by the scavengers of the deep, ere the second could have attached itself to the inner surface of its valve, and this smaller one must have lived and grown from its almost microscopic state of fry to the size of the second oyster probably of two years' growth-for the oysters of the chalk are small and thin. Suppose this: then it must have taken more than two years before the slowly-falling sediments of the Cretacoous Sea had accumulated to the extent of a few stout sheets of paper. Now the ordinary aggregate thickness of the three associated chalks, upper and lower white, and grey, is not much less than a thousand feet, and all this mass was formed at no greater maximum rate. The fossil shells and fish we find imbedded in its strata, of course lived and died in its waters-they were living-beings in those remote days. So self-evident does this fact seem,--although it was once stoutly discussed - that I have not dwelt upon it, nor shall $I$, as any doubts on this point will be swept away in the natural progress of our remarks. And yet the chalk is itself but a portion of the Cretaceous group or system of rocks, and that system but one amongst many systems formed at no quicker rate.

(To be continwed.)

\title{
FOREIGN CORRESPONDENCE.
}

By Dr. T. L. Phipson, of Paris.

Late Mortality amongst distinguished Geologists-Action of Water on Plutonic Rocks-Artificial Production of Minerals ; Aragonite formed in Steam Engines; Rubies and Sapphires-Oscillation of the North and South Coasts of France-The Sand of the Desert of SaharaThe Coryphodon-Newly discovered Foot-prints of Extinct AnimalsResearches on the Flora of the Tertiary Formations.

Before entering upon the regular correspondence with which we hope to entertain our readers each successive month, by making known to them every new and important geological fact as it comes 
to light in our part of the scientific world, we think it will not be without interest at the present moment, to east a rapid glance over some of the later and more remarkable geological observations made on the continent during the year which has just brought itself to a close.

It is with deep regret we must, in the first instance, inform our readers that the past year has been, for the science of geology, one of frequent and almost irreparable losses. One after another the names of some very eminent men have been erased from the list of the living.-While England deplores the death of Hugh Miller, Conybeare, Scoresby, and others whose reputations have not spread so widely, France feels how great is the loss she has just experienced by that of Constant Prévost, Dufrénoy, and D'Orbigny, who have opened more than one new and enlightened path in the obscure branches of their favourite science, and whose meritorious lives have not failed to excite a general admiration. Belgium has lost the eminent Dumont whose classifications of the Belgian strata and admirable geological maps have rendered his name immortal, and American science still mourns for the young and intrepid Dr. Kane, whose hazardous voyages of discovery and explorations of the Arctic Seas, have spread his fame far and wide. Germany has likewise suffered by the death of Dr. Lichtenstein, the learned director of the Geological Museum at Berlin, and the unrelenting hand of death, or rather, the accursed knife of a savage barbarian, has taken away from us the young and indefatigable African traveller, Dr. Vogel.

At one of the last meetings of the Congress of German Naturalists, it was proposed that an enormous erratic block of granite, measuring some six yards high, and from fifty to sixty yards in circumference, should be transformed into a monument to honour and perpetuate the memory of the illustrious Leopold Von Buch. The Congress received the proposition with acclamations of delight and immediately charged two of its members to superintend the operation. The eminent men whose names we have just mentioned, do they not, one and all, deserve also their block of granite?

In our idea nothing can be more interesting, and, at the same time, more important to geological science, than accurate investi. 
gation as to the manner in which minerals and rocks are formed and destroyed by nature.-Since the well known experiments of Sir James Hall, who transformed chalk into granular or saccharoïd limestone in a heated and hermetically closed gun barrel, many philosophers have attempted to produce in their laboratories, the mineral productions found in nature. These attempts have been attended, in many cases, with perfect success, and the list, already rather considerable, of artificially formed minerals, is daily increasing.

Whilst M. Daubrée has been calling the attention of the Academy of Sciences to the rapidity and ease with which the Feldspar rocks undergo decomposition by the action of water, M. Becquerel has investigated the action of pressure and high temperatures in the production of artificial minerals.-Every one has remarked the prodigious action which water exercises upon minerals in general, but, however paradoxical the assertion may appear, nowhere can this action be rendered more palpable than when it is brought to bear upon the plutonic or eruptive rocks, such as basalt, granite, protogine, feldspar, \&c., which, from their massive structure and hardness, would rather seem to be completely indestructible by an agent apparently so harmless as water. But these rocks contain, all of them, an alkaline silicate, soluble in water, and it is the separation and dissolution of this silicate that determines the decomposition and disaggregation of the rock. If we take, for instance, a piece of hard basalt, and grind it down in presence of water, the species of paste which is thus formed, presents, in a very short time, an alkaline reaction, rendered evident by test paper.-M. Daubrée has made a like experiment on a larger scale. He places in a barrel full of water, to which a movement of rotation is given, small fragments of quartz and feldspar. In a few hours the water contained in the barrel is found to have dissolved a considerable quantity of alkaline silicate,

M. Becquerel in order to obtain some idea of the chemical actions that have taken place in the sedimentary strata, at the time they were covered over, uplifted, and heated by the eruptive rocks, such as granite, porphyry, basalt, \&c., has minutely studied the 
influence of pressure and heat acting simultaneously upon different bodies whilst these bodies enter into chemical combination with one another. Nothing could be more simple than his mode of operating : Taking a thick glass tube, closed at one end, he places in it the substances intended to act upon each other, $i$. e., to produce the combination he desires. To procure a great pressure, he makes use of highly volatile substances, such as ether or bisulphide of carbon which he adds to the contents of the tube. The latter is then hermetically sealed and placed in an oven, to which, at will, a certain degree of heat (generally from 100 to 150 degrees centi-grade) can be given. In some cases Becquerel has added the action of a weak electric current to that exercised by heat and pressure in the experiments.

By operating in this manner he has lately obtained Malachite or carbonate of copper, exactly imitating the natural species; sulphide of silver, and Galena or sulphide of lead, have been obtained crystallised in thin laminæ. Some beautiful samples of sulphide of copper were also produced in six-sided prisms, bearing the same angles and modifications, as those produced by nature herself. Protoxide of copper was obtained in fine octahedrons, and Aragonite or dimorphous carbonate of lime, in straight rectangular prisms so large as to permit an easy estimation of their angles.

Before quitting the subject of Becquerel's experiments we would refer to an interesting fact, viz.: the formation of the last-named mineral species, in steam engines. The concretions formed in boilers of steam engines have been found, in cases where the incrustations were composed of carbonate of lime, to be almost always of that remarkable variety called Aragonite, distinguishable from the common carbonate or Iceland spar, not only by its prismatic crystals, but also by their hardness which enables them to scratch those of the ordinary calcareous spar. It would seem from the foregoing observations, and from those formerly made by Gustav Rose, in Poggendorff's Annales, that wherever carbonate of lime is precipitated at a high temperature, and under a certain degree of pressure, we have production of Aragonite. 
M. Gaudin has likewise been very successful of late in the production of artificial minerals. He has given us a recipe for making sapphires in a few minutes, with hardly any trouble and at an extremely small expense. We know that the precious stones Corindon, Ruby, Sapphive, \&c., are essentially formed of pure alumina, colored by very minute quantities of certain substances, the nature of which has not yet been perfectly determined. $M$. Gaudin, some time ago, obtained artificial rubies by melting alumina with a very small quantity of chromate of potash, but the process was rather a difficult one. He has lately made known an easier method by which he obtained an infinite number of minute crystals of alumina; these crystals were found to be, for the most part, transparent hexagonal tables, amongst which were secn. smaller ones, quite red, and of a rhomboidal form. Most of them were exceedingly minute, and their forms could only be thoroughly examined by the aid of a microscope, but, since then crystals large cnough to serve as pivots in watches, \&c., have been obtained. The experiment just referred to furnishes us with another incontestable proof that the hard mineral substances presented to us in nature under crystalized forms, have been produced by the agency of heat, and have certainly not been deposited from water, as the crystals produced in our laboratories, from solutions, or like the beautiful calcareous spar which is forming every day under our eyes, in the grottos of limestone districts.

M. Tessier on presenting to the Paris Academy of Sciences, last October, a piece of petrified wood from a submerged forest on the west of Normandy, spoke of an interesting geological phenomenon which is taking place daily on the French coasts. It appears from his statements, that whilst the MediterraneanSea is slowly retiring from the south coast of France, rendering these shores yearly broader and broader by the new made land or muddy deposits it is leaving behind, the North Sca, on the contrary, is forcing its way slowly but surely on the north-western coasts, gradually encroaching more and more upon the continent, and penetrating, in some places, to a considerable distance, into the neighbouring dry land. That this phenomenon has been at work for some time is proved by the fact that the ancient lighthouse of Boulogne, elevated during the reign of Caligula, and which was still standing in 
the fifteenth century, has since disappeared and is now nowhere to be seen; the sea has long ago swept it away, and hidden beneath its waves the spot upon which it stood. We have numerous examples in geology of this encroachment and retiring of the sea on or from the coasts of different continents, and we shall doubtless have frequent occasion to refer to them in some of our future articles. The uplifting of certain banks of shells, the sinking or lowering of monuments erected near the sea coast, procure us ample grounds for investigating the effects and causes of these phenomena; and the slow oscillatory movements noticed on the roasts of Sweden, Norway, Sicily, Sardinia, Italy, New Holland, certain parts of America, \&c., as well as the periodic, although irregularly altemating rise and fall of the water in the Caspian and Dead Seas, together with like phenomena already observed in the Coral Seas, show us, that without earthquakes, properly so called, the surface of the earth is capable of the same gentle and progressive oscillations as those which must have prevailed so generally in the earliest ages. One of the most curions oscillations of maritime shores, is that which, according to Belpaire, is going on at the present time along the coast of Flanders. If we are to believe the eminent naturalist just named, the Flemish coast, from the mouth of the river Scheld to the town of Calais, is undergoing a species of oscillation, the axis of which motion appears to be situated near the little town of Nieuport. The land which extends from Nieuport to the coast of Holland, appears to be gradually sinking, whilst the coast line from Nieuport to Calais seems to rise slowly out of the sea. The extent of this oscillatory motion has not yet been determined with certitude.- "The eastern "coast of the Scandinavian peninsula," says Humboldt, (*) " has "probably risen about 320 feet in 8,000 years. In 12,000 years, if " the movement be regular, parts of the bottom of the sea which " lie nearest the shores, and are in the present day covered by " nearly fifty fathoms of water, will come to the surface, and con"stitute dry land. But what are such intervals of time, compared " to the length of the geognostic periods revealed to us in the "stratified series of formations, and in the world of extinct and "varying organisms!" We may add with the same illustrious

(*) Cosmos, vol. 1, p. 302, Eng. Trans. by Otto. 
author that the phenomena to which we have just alluded remind us of the instability of the present order of things, and the changes to which the outlines and configurations of continents are probably still subject at long intervals of time.

Our distinguished friend, Dr. Van den Corput, during a recent travel in Africa, has paid particular attention to the sand of the great Desert of Sahara. The samples he has examined were collected from the north-easterly regions of the great desert, which covers a tract of land of about 300,000 square leagues, i.e., a superficies nearly three times that of the Mediterranean.* This sand is so white and of so fine a grain, that one could easily mistake it for pulverized glass. - Ehrenberg once professed the opinion that the sand of Sahara was chiefly formed of the remains of hosts of microscopic animalculi, resembling those discovered in the calcareous formations on both shores of the Nile.-Van den Corput assures us that this opinion, to say the least, is extremely exaggerated. In the microscopical investigations to which he submitted the sand of Sahara he discovered neither Infusoria, Foraminifera, or Diatomaceæ, and very few, if any, organic or calcareous remains. It appears formed, on the contrary, of extremely minute particles of pure quartz, having an irregular form and very sharp angles. The dimensions of the grains are much less than those of other similar deposits: Thus, whilst the grains of sand from the coast of the North Sea measure from 4-1000ths to 12-1000ths, and those of the tertiary beds, 8,16 , and 24-1000ths, the grains of sand from the great desert measure only from 1-1000th to 1-1000ths of an inch.-The author of these observations considers the Sahara sand as belonging to one of the most recent tertiary formations.

We will now turn our attention for a while to Palæontology.-It is not long since, that Professor Owen, from the examination of a single bone, or rather of a double tooth belonging to the lower jaw of an unknown animal, was bold enough to create a new genus of extinct pachyderms to which he gave the name of Coryphodon, - the tooth resembled somewhat that of a Tapir. The eminent palæontologist, M. Hébert, has since fully confirmed the generic distinction so sagaciously established by the illustrious English

* Compare lfumboldt : Views of Nature, Bohn's cdition, 1850, p, 89. 
zoologist : Not only is the new genus Coryphodon now perfectly established as such, but everything tends to prove that future researches will result in the discovery of intermediate forms, or genera of animals which are now wanting to fill up the gap existing between the genera Coryphodon and Lophiodon. M. Hébert has completed the entire dental system of the former, by the study of uinety teeth found in a more or less perfect state of preservation. Of these the canine teeth are more separated from the incisiva than in the Tapir; they are strong and very characteristic, resembling those of no other known animal living or fossil. It is now almost certain that there exist two species of Coryphodon: the first, called by Professor Owen, Coryphodon Eocenus, being more than twice as large as the second species, which M. Hebert has named Coryphodon Owenii. The latter of these two species was eertainly a larger animal than the Indian Tapir, the former must therefore have been a most prodigious.beast.

Whereas, in some instances, fossil remains and structores of organised beings are found perfectly preserved, even in their minutest details, in others the animal or plant has left nothing behind save a faint impression of its tissues, engraven on the hard sandstone or argillaceous rock whilst still in a soft state; one of the earliest discoveries of these impressions was made in Saxony, near Hildburghausen, by M. Kaup who found them on the surface of some slabs of variegated sandstone belonging to the Trias formation. M. Kaup and Alexander Von Humboldt regarded them as impressions of the feet of certain Mammalia to which the name Cheiratherium was given. This was rather a startling assertion, as no remains of Mammalia had ever been found in more ancient strata than the Tertiary.--Professor Owen, however, is of opinion that the foot prints in question were made by gigantic Batrachians.-Humboldt made known this important diseovery to the Paris Academy of Sciences on the 17th of August, 1835. Shortly afterwards numerous tridactyle markings were observed in the Valley of the Connecticut, but these appeared to have been produced by biped animals, and were doubtless impressions left on the soft mud of the Trias by certain varieties of extinct birds, whereas the former were positively the marks of quadrupeds-whether Mammalia or not remains to be learnt. M. 
Daubrée has just drawn our attention to a similar interesting discovery, which he has recently made in France. At Saint Valbert, between Plombières and Luxenil, there are some large quarries of Trias sandstone (variegated sandstone). It was in these quarries that the geologist we have just named, had the good luck to meet with impressions of the feet of quadrupeds in every respect similar to those formerly discovered at Hildburghausen, in Saxony. Undemeath the thick strata of red sandstone, which is extracted for building, paving, \&c., there exist thin layers of another sandstone, also of a reddish colour, but spotted with green, and alternating with layers of clay which show a like coloration. It was in these clay stratifications that M. Daubrée discovered the impressions we speak of : they were found on the surface of the beds of clay, where they join the superposed sandstone. No doubt exists as to the identity of the animal to which we owe these imprints in France, with the quadruped that produced them on the Trias formation in Saxony. At the side of the footprints of the larger feet were found also some much smaller, having only four toes, and reminding one of the feet of the Batrachian tribe. Not only the form of the feet, but the minutest details of the skin of the foot, are brought to light by a careful inspection of the foot-marks. After having thoroughly studied these and modelled, for the sake of comparison, some impressions of the feet of bears, kangaroos, crocodiles, lizards, \&c.* M. Daubrée comes to the conclusion that the quadruped who has left these traces behind him in the Trias formation of - Saint Valbert, must have belonged to the class of Mammalia. For our part, we feel more disposed however to adhere to Professor Owen's opinion alluded to above, at least until we shall have more evidence to the contrary than can be furnished by a mere foot-print.

The impressions left by animals who flourished on our planet in the earlier ages of the globe, teach us however some important geological lessons : They attest, in the first place, that the ground over which the animal walked was soft and damp, but nevertheless above water. But these sedimentary strata upon which the animal made his promenades, has since been covered by another deposit,

* These impressions were moulded in earth of the Trias formation, in which the ancient foodmarks were found. 
which has actually moulded itself upon the impression of the footprints left behind; and then again by another deposit of the same nature as the first, which can only have been deposited from the sea.* Therefore the ground of which we speak, must first of all have been lifted above the water, that terrestrial animals could have walked upon it; it must then have sunk down again beneath the sea to receive the sedimentary deposits it reveals, and lastly, must have been uplifted again to attain the position in which we see it at the present day.

These phenomena which are revealed to us by the study of the formations of bygone ages, are therefore intimately connected with those oscillatory motions of the soil which we observe now-a-days on the sea-coasts in many parts of the world, and to which we have already had occasion to allude.

We will close our short exposé by a glance at the Flora of the Tertiary periods, to which our attention has been recently called by the appearance of two admirable workst by the distinguished Professor Goeppert, of Breslau. In these works the learned author does not confine himself to the description of the fossil plants found in the tertiary beds of Schlossnitz and those of the Island of Java only; he moreover compares those with the whole known Flora of the tertiary formations in general, of which the different plants already amount to two thousand species.-This is also the first time that the fossil flora of tropical regions, situated far from Europe, have been compared with the tertiary flora of our own latitudes.

The principal families of which representatives have been found by Professor Goeppert in the Schlossnitz strata are as follows :Corylaceæ, of which there are twenty-eight species; Calicacæ, nineteen; Betulacex, eighteen ; Ulmaceæ, eleven ; Pinaceæ, six ; Papillionaceæ, six ; Aceraceæ, seven ; Rosaceæ, four; Juglandaceæ, three ; Combretaceæ, two; \&c.-Professor Agassiz once remarked, if we are not mistaken, that no representatives of the family of Rosacer had ever been found fossil; it would appear from his statements

* This is rendered evident by the remains of marine shells, \&c.

† Die Terticre Flora von Schlossnitz in 4to Leipzig 1855; and Die Tertiere Flora. auf der Insel Java, in 4to Elberield, 1857. 
that these most useful plants, amongst which we find the apple, the pear, the medlar, the strawberry, the peach, the apricot, the almond, the plum, \&c., \&c., only made their appearance on the globe with the advent of man. We see, however, by the above, that four species of the Rosacer family have been detected in the Schlossnitz Tertiary by Professor Groeppert.

For the materials upon which Professor Goeppert has worked to form his tertiary flora of Java, he is indebted to M. Junghuhn, the ingenious naturalist to whom we owe a detailed description of the geology of this interesting island, published in Dutch and German. -The fossils of Java appear to belong to the Eocene period, i.e., to the oldest Tertiary beds. A singular circumstance immediately strikes us as we examine these fossils; the petrified trunks of trees that have been brought to light in the tertiary formations of Java are, withont exception, Dicotyledonous plants, whilst the forests that flourish at the present time on the island are composed of palms and arborescent ferns. However we must not attach too great an importance to this fact, for, the other fossils, i.e., those not petrified, found in these regions, seem to imply that it is merely an accidental occurrence.

The number of species collected by M. Junghuhn amounts only to thirty-nine, amongst which we find : six Palms, five Lauracea, five Celastraeæ, three Magnoliaceæ, three Coryloceæ (all belonging to the genus Quercus), three Pipraceæ, two plants of the genus Ficus, two Apocynaceæ, two Rhamnaceæ; of the Musaceæ, Malpighiaceæ, Zingiberaceæ, Cornaceæ, and Ebenacæ, each one; we have also a species of Fungus, and three doubtful genera.

This small collection however is sufficient to rivet our attention on two striking facts : 1 st. The plants of which it is composed are all new; 2nd. The families to which they belong still abound in Java. The regetative system of this island has therefore not changed since the tertiary periods-which is contrary to what we observe in Furope-the whole of the species discovered as yet and a few genera only, are alone found to be different. 